\title{
A model for the transfer of conformational change in the phospholipid headgroup towards the hydrophobic interior of the membrane via a phosphorus $(V)$ trigonal bipyramidal intermediate
}

Citation for published version (APA):

Merkelbach, I. I., \& Buck, H. M. (1983). A model for the transfer of conformational change in the phospholipid headgroup towards the hydrophobic interior of the membrane via a phosphorus $(\mathrm{V})$ trigonal bipyramidal intermediate. Recueil des Travaux Chimiques des Pays-Bas, 102(5), 283-284.

https://doi.org/10.1002/recl.19831020506

DOI:

10.1002/recl.19831020506

Document status and date:

Published: 01/01/1983

Document Version:

Publisher's PDF, also known as Version of Record (includes final page, issue and volume numbers)

Please check the document version of this publication:

- A submitted manuscript is the version of the article upon submission and before peer-review. There can be important differences between the submitted version and the official published version of record. People interested in the research are advised to contact the author for the final version of the publication, or visit the $\mathrm{DOI}$ to the publisher's website.

- The final author version and the galley proof are versions of the publication after peer review.

- The final published version features the final layout of the paper including the volume, issue and page numbers.

Link to publication

\footnotetext{
General rights

- You may freely distribute the URL identifying the publication in the public portal. follow below link for the End User Agreement:

www.tue.nl/taverne

Take down policy

If you believe that this document breaches copyright please contact us at:

openaccess@tue.nl

providing details and we will investigate your claim.
}

Copyright and moral rights for the publications made accessible in the public portal are retained by the authors and/or other copyright owners and it is a condition of accessing publications that users recognise and abide by the legal requirements associated with these rights.

- Users may download and print one copy of any publication from the public portal for the purpose of private study or research.

- You may not further distribute the material or use it for any profit-making activity or commercial gain

If the publication is distributed under the terms of Article $25 \mathrm{fa}$ of the Dutch Copyright Act, indicated by the "Taverne" license above, please 


\section{Preliminary Communication}

Recl. Trav. Chim. Pays-Bas 102, 283-284 (1983)

A Model for the Transfer of Conformational Change in the Phospholipid Beadgroup towards the Hyarophobic Interior of the Membrane via a $\mathrm{P}^{\mathrm{V}}$ Trigonal Bipyramidal Intermediate

Ingrid I. Merkelbach and Henk M. Buck

Eindhoven University of Technology, Department of Organie Chemistry, The Nethertands

(Received Febmary 24th, 1983)

Abstract: Co-ordination change of phosphorus may be responsible for a decrease of the cross-sectional area of the phospholipid headgroup and a reduction of the difference in effective chain length between both acyl chains of a phospholipid molecule. Both factors induce a change in the angle of tilt of the acyl chains, leading to increasing or decreasing lateral phase separation,

Recently, the coexistence of liquid-crystaliine and gel-like domains (clusters) is reported for mixtures of phosphatidylcholine (PC) with phosphatidylethanolamine (PE) ${ }^{1}$, cholestero ${ }^{2}$ or proteins ${ }^{3}$. This occurs in the phase transition region, ranging from the main phase transition temperature down to a temperature around the pretransition. It should be seen as a continuously varying degree of congregation of more ordered molecules in a liquid-crystalline matrix and vice versa, effectuating a gradual increasing or decreasing lateral phase separation. The resulting variation in molecular density is accompanied by a local vaxiation in the angle of tilt of the lipid hydrocarbon chains relative to the bilayer-normal. The degree of lateral phase separation will depend on internal factors as miscibility ${ }^{4}$ and interaction energies between the constituents ${ }^{3}$ and can, besides by temperature, be influenced by a number of excernal factors e.g. water content ${ }^{5}$, proton and cation concentration ${ }^{6}$, ionic strength ${ }^{6}$ and potential field ${ }^{7}$. For the physiological process of the excitation of an axon ${ }^{8}$, we propose a model in which a change in the degree of phase separation originates in the headgroup of the phospholipids, at the level of an interconversion of $P^{I V}$ into $P^{V}$ trigonal bipyramidal intermediate (TBP). This $P$ geometry effectuates a decrease in cross-sectional area of the phospholipid headgroup and diminishes the difference in chair length between the lipid hydrocarbon chains. As will be explained, both factors will change the angle of tilt of the hydrocarbon chains, which will lead to the lateral phase separation. During the excitation of an axon the decrease in cross-sectional area of the heađgroup is visualized at a molecular level by the following changes. $\mathrm{Ca}^{2+}$ ions desorb from the outer monolayer of the membrane ${ }^{9}$ and the charge at the inside of the membrane inverts from negative to positive ${ }^{8}$. By these changes the headgroup is no longer forced in an extended and inward pulled conformation and gets the opportunity to reorientate, as can be seen in the figure.
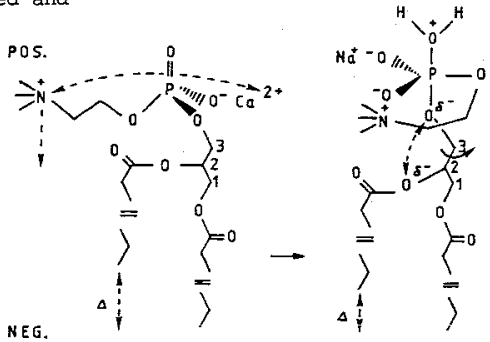
The existing $\mathrm{P}^{\mathrm{IV}}=\mathrm{P}^{\mathrm{V}}$ equilibrium, under 'resting' conditions laying at the side of the $\mathrm{p}^{\mathrm{IV}}$ compound, will be shifted in the direction of the $\mathrm{P}^{\mathrm{V}}$ intermediate, because this conformation is stabilized by the formation of a diequatorial pseudo six-membered ring. The positively charged nitrogen of the choline headgroup shields the negative charge of the formerly dowble bonded oxygen, thus polarizing the $\mathrm{P}=0$ bond, by which the electrophilicity of the phosphorus atom will be increased. 10 . This process will be promoted by the nucleophilic attack of a water molecule, normally present in excess in the headgroup layer of the membrane, thus generating a $\mathrm{p}^{\mathrm{V}} \mathrm{TBP}$ intermediate. In molecules as PC, where the headgroup in 'stretched' form will occupy a greatex excluded cross-sectional axea than the lipid hydrocarbon chains ${ }^{2}$, the chalns oxi'ginally adopted a tilted conformation to fill in a potential voif in the hydrocarbon chain region ${ }^{2}$. The decrease in cross-sectional area of the headgroup due to ringformation, will cause decrease in the angle of tilt of the hydrocarbon chains. PE and N-methyl and N,N-dimethyl PE do not exhibit such pretransition behaviour due to the smaller excluded area of the headgroup in 'stretched' conformation ${ }^{11}$. The reduction of the difference in chain length between the hydrocarbon chains, originates in the increased electron density accumulated on the apical ligands in a $\mathrm{P}^{\mathrm{V}}$ TBP geometry ${ }^{10}$. The increase in electron density on the apical oxygen, through which the phosphate is bound to the glycerol backbone, brings about a repulsion of the sn-2 oxygen, as indicated in the figure. This repulsion is theoretically verified for the $\mathrm{P}^{\mathrm{V}}$ TBP model compound derived from tetrahydrofurfurylphosphate, in which the same $0-C-C-O-P$ sequence occurs at the apical position in a TBP intermediate ${ }^{12}$. Rotation around the $C_{2}-C_{3}$ bond of the glycerol backbone shifts the sn-2 chain in the direction normal to the bilayer and reduces the difference in effective chain length between the hydrocarbon chains. Comparison of ${ }^{13} \mathrm{C}$ and ${ }^{2}$ H NMR spectra of phospholipids, labelled respectively with ${ }^{13} \mathrm{C}$ at the sn-2 carbonyl group and with ${ }^{2} \mathrm{H}$ at the 4 -position of the sn-2 chain, suggests that a conformational change of the carbonyl group precedes chain melting on increasing temperature ${ }^{1}$. Moreover PCs with miristoyl, palmitoyl and stearoyl chains at the sn-1 and/or sn-2 position show strong dependence of the pretransition behaviour on composition ${ }^{13}$. Co-operative change in the angle of tilt of a number of phospholipid molecules is needed to maximize the van der wals interactions between neighbouring acyl chains. This will lead at macromolecular level to the formation of a cluster with an angle of tilt differing from the surrounding matrix. The relaxation time of such a cluster is appreciable greater than that for other characteristic movements of the molecu$1 \mathrm{e}^{14}$. The short-living $\mathrm{P}$ IBP intermediate initiates the formation of a cluster with a much longer life-time, through which a timescale can be reached at which physiological processes (like those occurring during a nerve impulse) can take place ${ }^{15}$.

It is tempting to correlate the $\mathrm{Na}^{+}$channel opening during the excitation of an axon to a change in degree of lateral phase separation of the membxane-protein system. The hysteresis between the fast order-disorder transition and the relative slow disorder-order transition makes a lipid bilayer extremely suitable to follow oscillating processes and to store short-living information, as required to pass a nerve impulse ${ }^{15}$. Measurements of valinomycin-mediated potassium conductivity around the region of lateral phase separation in binary mixtures show a pronounced maximum in electrical conductivity at the main phase transition temperature ${ }^{16}$. one can imagine an integral protein in a fluid environment to be free to adopt the tertiary structure recessary to function as an ion channel. A gel-like matrix can displace some special group of the channel-forming protein out of its critical position ${ }^{17}$ and/or disturb an unundexbroken protein in helix form ${ }^{18}$. It might offer support for the above mentioned supposition that 2-amido-PC, contrary to PC, is found to be inhibitory for integral proteins ${ }^{19}$. The oxygen esterified to $C_{2}$ of the glycerol backbone is essential for the transfer of the conformational change in the headgroup towards the difference in chain length between the hydrocarbon chains. If this oxygen is replaced by the less electronegative nitrogen, less repulsion and resulting acyl chain shift will be expected. Moreover, the hydrogen bridge found in $\mathrm{X}$-ray analyses of comparable lipids ${ }^{20}$, will hinder acyl chain shift and headgroup reorientation.

\section{References}

1. A. BZume, R.J. Wittebort, S.K. Das Gupta and R.G. Griffin, Biochemistry 21, 6243 (1982).

2. F.T. Presti, R.J. Pace and S.I. Chan, Biochemistry 21, 3831 (1982).

3. T. Lookman, D.A. Pink, E.W. Gxrmdke, M.J. Zuckermann and F. de Verteuit, Biochemistry 21, 5593 (1982).

4. S.H. Wu and H.M. Mc.ConneZZ, Biochemistry 14, 847 (1975).

5. A. Tardieu, V. Luzzati and F.C. Remon, J. Mol. Biol. 75., 711, (1973).

6. S. Tokutomi, K. Ohki and S.I. Ohnishi, Biochim. Biophys. Acta 596, 192 (1980).

7. F. Jthnig, K. Harlos, H. Vogel and H. Eibl, Biochemistry 18, 1459 (1979).

8. B. Hille, Progx. Biophys. Mol. Biol. 21, 1 (1970).

9. H.C. Luttgau and H.G. Glitsch, Fortschr. Zool. 24, 1 (1976).

10. "Reaction mechanisms in organophosphorus chemistry", Thesis, A.M.C.F. Castelijns, 1979.

11. D.J. Vaughon and K.M. Keough, FEBS Lett. 47, 158 (1974).

12. J.J.C. von Lier, L.H. Koole and H.M. Buck, Recl. Trav. Chim. Pays-Bas 102, 148 (1983).

13. S.C. Chen and J.M. Sturtevant, Biochemistry 20, 713 (1981).

14. A.G. Lee, N.J.M. Birdsalt, J.C. Metcalfe, F.A. Toon and G.B. Warren, Biochemistry 13, 3699 (1974).

15. H. Trunble, Naturwissensch. 58, 277 (1971).

16. S.K. Wu, Diss. Abstr. Int. B 35,4413 (1975).

17. B. Hille, J. Gen. Physiol. 66, 535 (1975).

18. W. Veatch, S. Weinstein, B.A. WaZlace and E.R. Blout, Pept. Struct. Biol Funct., Proc. Am. Pept., Symp. 6th, 635 (1979).

19. N.S. Chandrakumar and J. Hajdz, J. Org. Chem. 47, 2144 (1982).

20. I. Pascher and S. SundeZZ, Chem. Phys. Lipids 20, 175 (1977). 